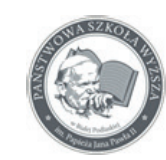

Authors' contribution/

Wkład autorów:

A. Zaplanowanie badań/

Study design

B. Zebranie danych/

Data collection

C. Analiza statystyczna/

Statistical analysis

D. Interpretacja danych/

Data interpretation

E. Przygotowanie tekstu/

Manuscript preparation

F. Opracowanie

piśmiennictwa/

Literature search

G. Pozyskanie funduszy/

Funds collection
ISSN 2083-3725

\section{A REVIEW OF THE BOOK TITLED \\ “SOCIAL CAPITAL IN CROSS-BORDER NETWORK COOPERATION OF BIAŁA PODLASKA AND BREST", DAWID BŁASZCZAK, PSW JPII, BIAŁA PODLASKA 2016, PP. 256}

\author{
RECENZJA KSIĄŻKI PT. \\ „KAPITAŁ SPOŁECZNY W SIECI WSPÓŁPRACY TRANSGRANICZNEJ \\ BIAŁEJ PODLASKIEJ I BRZEŚCIA", \\ DAWID BŁASZCZAK, PSW JPII, BIAŁA PODLASKA 2016, S. 256
}

\section{Sandra Tur}

Pope John II State School of Higher Education in Biała Podlaska

Państwowa Szkoła Wyższa im. Papieża Jana Pawła II w Białej Podlaskiej

Tur S. (2017), A review of the book titled "Social capital in cross-border network cooperation of Biała Podlaska and Brest”, Dawid Błaszczak, PSW JPII, Biała Podlaska 2016, pp. 256/ Recenzja książki pt. „Kapitał społeczny w sieci współpracy transgranicznej Białej Podlaskiej i Brześcia”, Dawid Błaszczak, PSW JPII, Biała Podlaska 2016, s. 256. Economic and Regional Studies. Vol. 10, No. 1, pp. 128-131. https://doi.org/10.2478/ers-2017-0010

Social capital is an extremely important issue which in the sociological discourse occupies the leading position. However, the comparison of social capital with research on networking in the cross-border space has not been the focus of many publications. The publication of Dr Dawid Błaszczak (PhD) is undoubtedly a work that fills the gap in this field and at the same time broadens the application range of network research. "Social capital in crossborder network cooperation of Biała Podlaska and Brest" is a significant publication for several reasons:

- social capital substantially affects the scope, type and quality of cooperation, due to the accumulation of resources such as trust, solidarity, cohesion, etc.

- development of social networks facilitates cooperation and considerably contributes to its acceleration. On the other hand, social networks are a response to the contemporary economic conditions, which, in order to be propagated, require the existence of connections and information flow.

- in the context of relations between countries, the traditional concept of borders undergoes transformation owing to the functioning connections, various kinds of flows or through the technological development that has changed the perception of time and space.

- the social network concept is used to capture the movement of social capital, which is a valuable contribution to the development of
Kapitał społeczny jest niezwykle ważnym zagadnieniem, które w socjologicznym dyskursie zajmuje czołową pozycję. Natomiast zestawienie kapitału społecznego z badaniami sieci w przestrzeni transgranicznej nie doczekało się wielu publikacji. Publikacja doktora Dawida Błaszczaka jest niewątpliwie pozycją, która uzupełnia lukę w tym zakresie i jednocześnie poszerza zakres wykorzystania badań sieciowych. „Kapitał społeczny w sieci współpracy transgarnicznej Białej Podlaskiej i Brześcia” jest publikacją istotną z kilku powodów:

- kapitał społeczny w zasadniczy sposób wpływa na zakres, rodzaj i jakość współpracy, dzięki kumulacji takich zasobów, jak zaufanie, solidaryzm, spójność, itp.

- rozwój sieci społecznych ułatwia współpracę, ale i też w znacznym stopniu ją przyśpiesza. Z drugiej strony sieci społeczne są odpowiedzią na współczesną sytuację gospodarczą, która aby się rozprzestrzeniać wymaga właśnie istnienia powiązań, przepływu informacji.

- w kontekście powiązań między państwami, tradycyjne ujęcie granicy, ulega transformacji dzięki funkcjonującym powiązaniom, przepływom czy dzięki rozwojowi technologicznemu, który zmienił postrzeganie czasu i przestrzeni.

- sieć społeczna jest wykorzystana w celu uchwycenia przepływu kapitału społecznego, co jest cennym wkładem w rozwoju badań sieciowych ze względu na wykorzystywane wskaźniki do analizy i interpretacji.

Address for correspondence/ Adres korespondencyjny: dr Sandra Tur, Państwowa Szkoła Wyższa im. Papieża Jana Pawła II w Białej Podlaskiej, Wydział Nauk o Zdrowiu i Nauk Społecznych, Zakład Socjologii, ul. Sidorska 102, 21-500 Biała Podlaska, Polska; tel. +48 83 344-99-11; e-mail: sa-sandra@wp.pl Journal indexed in/ Czasopismo indeksowane w: AgEcon Search, AGRO, BazEkon, Index Copernicus Journal Master List, ICV 2015: 81,26; Polish Ministry of Science and Higher Education 2016: 9 points/ AgEcon Search, AGRO, BazEkon, Index Copernicus Journal Master List ICV 2015: 81,26; Ministerstwie Nauki i Szkolnictwa Wyższego 2016: 9 punktów. Copyright: (C) 2016 Pope John Paul II State School of Higher Education in Biała Podlaska, Sandra Tur. All articles are distributed under the terms of the Creative Commons Attribution-NonCommercial-ShareAlike 4.0 International (CC BY-NC-SA 4.0) License (http://creativecommons.org/licenses/by-nc-sa/4.0/), allowing third parties to copy and redistribute the material in any medium or format and to remix, transform, and build upon the material, provided the original work is properly cited and states its license. 
network research owing to the indicators used for analysis and interpretation.

The book has all the features of a scientific monograph containing:

- an original interpretation of social capital in the network of cross-border cooperation,

- solid theoretical foundations and references to both Polish and foreign contemporary literature on this field,

- application of social network analysis in developing the results of proprietary empirical research and innovative analyses based on the cited theories and concepts,

- references to the contemporary socio-economic practice.

The book pays attention to the following groups of problems:

- application of network research in social sciences, including social capital in the context of the research on borderline areas,

- social networks as a paradigm of cross-border cooperation structures,

- functional Areas as examples of network cooperation platforms,

- the use of social capital resources in the realisation of cross-border policy in Biała Podlaska and Brest,

- cross-border partnership in the discussed area.

The book consists of five chapters arranged in an appropriate order which allows for expanding the knowledge on the subject in question. The first chapter deals with network research. Basic issues related to network connections and the use of research for the analysis of social processes are examined. The second chapter deals with research on social capital in systems of network relationships. The classical concepts of social capital in the context of networks, investigated by such authors as R. Putnam, J. Coleman, P. Bourdieu and F. Fukuyama, are discussed thoroughly. Classic theories were enriched with references to authors who have drawn comparisons between social networks and the concept of social capital: A. Krishna and E. Shrader, P. Adler and S-W. Kwon, J. Nahapiet and S. Ghostal, P. Bullen and J. Onyx. Separate subsections are dedicated to the concept of "structural holes" by R.S Burt, social capital in the network theory of N. Lin and the importance of "strong" and "weak" ties by M. Granovetter. The third chapter is focused on the issues of borders and transborderism in various sociological perspectives. The field which is broadly discussed is the functional area which aims at consolidating spatial order in the spatial development policy. An example of the discussed concept is the networking mechanism of the Urban Functional Area (UFA) of Biała Podlaska and the Border Functional Area (BFA) "Active Borderland", which has been enriched with the network analysis of selected issues from the strategy of BFA "Active Borderland" and UFA Biała Podlaska, developed by the author of the monograph. The fourth chapter presents the methodology of the author's own research, taking into account the specific network connections of Biała Podlaska and
Książka posiada wszelkie cechy monografii naukowej zawierającej:

- oryginalną interpretację kapitału społecznego w sieci transgranicznej współpracy,

- silne osadzenie w teorii i współczesnej literaturze polskiej, jak i zagranicznej,

- wykorzystanie analizy sieci społecznych do opracowania wyników własnych badań empirycznych oraz nowatorskich analiz opartych na przytoczonych teoriach i koncepcjach,

- nawiązanie do współczesnej praktyki społeczno-gospodarczej.

W książce zwrócono uwagę na następujące grupy problemów:

- wykorzystanie badań sieciowych w naukach społecznych z uwzględnieniem kapitału społecznego w kontekście badań pogranicza,

- sieci społeczne jako paradygmat struktur współpracy transgranicznej,

- Obszary Funkcjonalne jako przykłady płaszczyzn sieciowej współpracy,

- wykorzystanie zasobów kapitału społecznego w realizacji polityki transgranicznej Białej Podlaskiej i Brześcia,

- partnerstwo transgraniczne na omawianym obszarze.

Książka składa się z pięciu rozdziałów ułożonych we właściwej sekwencji umożliwiającej przechodzenie do pogłębiania wiedzy w omawianym przedmiocie. Pierwszy rozdział dotyczy badań sieciowych. Omawiane sa podstawowe zagadnienia związane z sieciowymi powiązaniami oraz wykorzystaniem badań do analizy procesów społecznych. Drugi rozdział dotyczy badań kapitału społecznego w układach sieciowych relacji. Omówione zostały dokładnie klasyczne koncepcje kapitału społecznego w kontekście sieci takich autorów, jak: R. Putnam, J. Coleman, P. Bourdieu oraz F. Fukuyama. Klasyczne teorie wzbogacone zostały o autorów, którzy zestawili sieci społeczne z koncepcją kapitału społecznego: A. Krishna i E. Shrader, P. Adler i S-W. Kwon, J. Nahapiet i S. Ghostal, P. Bullen i J. Onyx. Osobne podrozdziały poświęcone zostały koncepcji „luk strukturalnych” R.S. Burta, społecznego kapitału w teorii sieciowej N. Lin’a i znaczeniu „silnych” i „słabych” więzi M. Granovetter'a. Rozdział trzeci poświęcony został problematyce granic, transgraniczności w różnych perspektywach socjologicznych. Szeroko omawianą płaszczyzną jest obszar funkcjonalny, którego celem jest utrwalenie ładu przestrzennego w polityce przestrzennego zagospodarowania. Przykładem omawianego pojęcia jest sieciowość Miejskiego Obszaru Funkcjonalnego Biała Podlaska i Przygranicznego Obszaru Funkcjonalnego „Aktywne Pogranicze”, który wzbogacony został o analizę sieciową wybranych zagadnień ze strategii POF „Aktywne Pogranicze” i MOF Biała Podlaska opracowanych przez autora monografii. Rozdział czwarty przedstawia metodologię badań własnych autora $\mathrm{z}$ uwzględnieniem konkretnych powiązań sieciowych Białej Podlaskiej i Brześcia - program PHARE, Fundusz Małych Projektów Narodowego Programu dla Polski i program INTERREG 2004-2006. Całość rozdziału opatrzona 
Brest - the PHARE program, the Small Projects Fund of the National Programme for the Poland, as well as the INTERREG 2004-2006 program. The author furnished the whole chapter with insightful analysis of network interrelations between the discussed structures and programs. The fifth chapter presents the analysis of the network connections within the cross-border partnership of Biała Podlaska and Brest. The author chose three examples of partnership for the study: the Cross-Border Cooperation Programme PL-BY-UA 2007-2013, Support Programme for CrossBorder Initiatives in the Bug Euroregion and PolishBelarusian Economic Forum "Good Neighbourliness 2011". Both the fourth and the fifth chapter contain numerous graphical elaborations of network interrelations in the investigated area. The graphs are clear, perceptive and accompanied by thorough descriptions. They provide a very good complement to theoretical considerations and at the same time validate the theories and concepts selected by the author.

Through his personal research, studies and network analysis Dr Dawid Błaszczak answers the following research questions:

- What is the contribution of individual institutions to cross-border cooperation? Is it "balanced" or is it dominated by certain entities?

- What is the predominant form of the analyzed networks of cooperation? Are they centralized, closed, or composed of unconnected components?

- Is there a large number of entities with a high "node level" in the network? Do public or nonpublic entities constitute such nodes?

- Are the analysed network structures characterised by a high-density coefficient?

- Are the analysed networks dominated by strong or weak connections? How does the intensity of connections affect access to other actors and resources within the network?

- To what extent do various structures allow access to other actors, resources and control over these resources?

Answers to the formulated research questions arise while reading the following empirical chapters, in which the author provides them with the help of the graphic analysis of networks and their insightful description. The conclusion, on the other hand, is a reference point for the presented research questions and contains their summary, accompanied by the author's commentary, with considerations for the current Polish and Belarusian political and economic context.

The author presents and analyzes contemporary mechanisms of cooperation, which form an integrated approach to opportunities for stimulating partnership of Poland and Belarus. The book is highly interesting and explorative owing to both its great erudition, as regards familiarity with ample knowledge offered by the literature on this field, and good orientation in the practical functioning of economics and politics, as well as due to its capability of holistic approach, interpretation and arriving at general conclusions. jest o wnikliwe analizy autora sieciowych powiązań omawianych struktur i programów. Rozdział piąty natomiast przedstawia analizę powiązań sieciowych w partnerstwie transgranicznym Białej Podlaskiej i Brześcia. Do opracowania autor wybrał trzy przykłady partnerstwa: Program Współpracy Transgranicznej PL-BY-UA 2007-2013, Program Wspierania Inicjatyw Transgranicznych W Euroregionie Bug i Polsko-Białoruskie Forum Gospodarcze „Dobrosąsiedztwo 2011". Zarówno rozdział czwarty, jak i piąty zawiera liczne opracowania graficzne sieciowych powiązań omawianego przedmiotu. Grafy są przejrzyste, wnikliwe oraz opatrzone wyczerpującym opisem. Stanowią bardzo dobre dopełnienie rozważań teoretycznych, co jednocześnie uwiarygodnia wybrane teorie i koncepcje przez autora.

Doktor Dawid Błaszczak dzięki badaniom własnym, opracowaniom sieciowym i analizie odpowiada na następujące pytania badawcze:

- Jaki jest udział poszczególnych instytucji we współpracy transgranicznej? Czy ma charakter „zrównoważony”, czy jest zdominowany przez określone podmioty?

- Jaki jest dominujący kształt analizowanych sieci współpracy? Czy są scentralizowane, zamknięte, czy też złożone z niepołączonych ze sobą komponentów?

- Czy w sieci występuje duża ilość podmiotów o wysokim „stopniu węzła”? Czy węzłami takimi są podmioty publiczne czy niepubliczne?

- Czy analizowane struktury sieciowe cechuje duży wskaźnik gęstości?

- Czy analizowane sieci zdominowane są przez silne czy słabe powiązania? Jak intensywność powiązań wpływa na dostęp do innych aktorów i zasobów w sieci?

- W jakim stopniu różne struktury umożliwiają dostęp do innych aktorów i zasobów oraz kontrolę nad tymi zasobami?

Odpowiedzi na postawione pytania badawcze nasuwają się $\mathrm{w}$ trakcie czytania kolejnych rozdziałów empirycznych, w których autor, dzięki analizie graficznej sieci i wnikliwemu opisowi, ich udziela. Natomiast zakończenie jest punktem odniesienia do prezentowanych pytań badawczych i stanowi ich podsumowanie, opatrzone komentarzem autora z uwzględnieniem współczesnego kontekstu gospodarczo-politycznego Polski i Białorusi.

Autor przedstawia i analizuje współczesne mechanizmy współpracy, stanowiące zintegrowane podejście do możliwości stymulowania partnerstwa Polski i Białorusi. Książka jest niezwykle interesująca i odkrywcza zarówno dzięki wielkiej erudycji odnoszącej się do znajomości bogactwa treści wynikającej z literatury jak i dobrej orientacji w praktycznym funkcjonowaniu gospodarki i polityki, a także z umiejętności holistycznego spojrzenia i umiejętności interpretacji oraz wyciągania wniosków ogólnych. Głównym przedmiotem książki jest kapitał społeczny w sieci współpracy transgranicznej. Przestrzeń ta analizowana jest z szerokiej perspektywy: mikro i makro. Poziom mikro obejmują grafy przedstawiające liczne przepływy osób czy zasobów w tran- 
The main subject of the book is social capital in the network of cross-border cooperation. This space is analysed from a broad perspective: micro and macro. The micro level includes graphs showing numerous movements of people or resources in cross-border cooperation. The macro level, on the other hand, can be observed in the graphical presentation of networking entities, municipalities or communes and partners. The development and analysis of graphs by the author of the book is an extremely valuable contribution to Polish literature, social networks and cross-border cooperation. It is also an interesting and original way of incorporating the concept of social capital in a cross-border system. The structure of the book and the method of presentation can be assessed very highly. The book is not only well rooted in the literature of the problem and the subject of research, and uses original social network analysis and data from different sources, but it is also set in the contemporary economic and political reality, which makes it easier to understand the presented content. sgranicznej współpracy. Natomiast poziom makro zaobserwować można w graficznym przedstawieniu sieci współpracy podmiotów, gmin czy partnerów. Opracowanie i analiza grafów przez autora książki jest niezwykle cennym wkładem w polskiej literaturze sieci społecznych czy współpracy transgranicznej. Jest to również ciekawe i oryginalne osadzenie koncepcji kapitału społecznego w układzie transgraicznym. Struktura książki, jak i sposób prezentacji można ocenić bardzo wysoko. Książka jest nie tylko dobrze osadzona w literaturze problemu i przedmiotu badań oraz wykorzystuje oryginalne analizy sieci społecznych i dane liczbowe z różnych źródeł, jest też osadzona we współczesnych realiach gospodarczo-politycznych, które ułatwiają zrozumienie prezentowanych treści. 